Selcuk Journal of Agriculture and Food Sciences

http://sjafs.selcuk.edu.tr/sjafs/index

Research Article
SJAFS

(2021) 35 (2), 101-107

e-ISSN: 2458-8377

DOI:10.15316/SJAFS.2021.235

\title{
The Incidence Rate of White Rot (Sclerotinia sclerotiorum (Lib.) de Bary) Disease in Sunflower Cultivation Areas in Konya and Aksaray Provinces and its Pathogenic Potential
}

(D) Raziye KOÇAK ${ }^{1, *}$, ID Nuh BOYRAZ²

${ }^{1}$ Selçuk University, Çumra Vocational School, Animal and Plant Production Department, Konya, Turkey

${ }^{2}$ Selçuk University, Faculty of Agriculture, Department of Plant Protection, Konya, Turkey

\begin{tabular}{l}
\hline ARTICLE INFO \\
\hline Article history: \\
Received date: 03.05 .2021 \\
Accepted date: 03.06 .2021 \\
\hline
\end{tabular}

Keywords:

Sunflower

White rot

Sclerotinia sclerotiorum

Konya

Aksaray

\begin{abstract}
This study was conducted between June-September 2017-2018 in sunflower cultivation areas of Konya and Aksaray to determine the incidence rate of white rot disease and its pathogenic potential and to identify the disease agent Sclerotinia spp., Surveys were carried out 11,750 decares in total from Karatay, Altınekin, Cihanbeyli, Karapınar, Kadınhanı and Çumra districts of Konya province and 3000 decares in total from Centre of Aksaray (Hırkatol and Topakkaya village) and Eskil districts of Aksaray province. In the study, it was determined that the isolates obtained from diseased plants belong to Sclerotinia sclerotiorum (Lib.) de Bary. Although the disease was not seen in the first year in Konya, the disease rate in Altınekin district was determined as $9.38 \%$ in the second year. As a result of the survey studies, the disease rate in the Center of Aksaray in 2017 and 2018, respectively, was 2.83\% and 3.97\%; in Eskil, while no disease was occurred in the first year, it was determined at a rate of $4.16 \%$ in 2018. In the pathogenicity tests carried out with sunflower seedlings using approximately $20 \%$ of the isolates, it was found that the disease severity of the isolates varied between $56 \%$ and $66 \%$ and the difference between the disease severity and scale values of the isolates was statistically significant $(\mathrm{P}<0.05)$. Aksaray / Hirkatol was found to be the most virulent isolate in the pathogenicity test.
\end{abstract}

\section{Introduction}

Sunflower (Helianthus annuus L.), which ranks fourth in the world and is one of the most important oil plants, is essential in terms of vegetable crude oil production due to the high oil content $(22-50 \%)$ in its seed (Tekçe 2015).

It also ranks first in terms of cultivation area and production among the oilseed plants cultivated in our country. The highest amount of sunflower for oil is produced in the Thrace-Marmara Region (47.2\%), followed by the Central Anatolia Region (29.2\%). As a snack, it is mostly produced in the Central and Eastern Anatolia Regions (Anonymous 2016).

Many investigations are being carried out in order to expand the production areas of oilseed plants, which will be the raw material for vegetable oil production in Turkey. Accordingly, sunflower cultivation for oil is

\footnotetext{
* Corresponding author email: rkocak@selcuk.edu.tr

** This study has been produced from a part of the first author's doctorate thesis prepared under the supervision of the second author.
}

also encouraged in the irrigable areas of provinces in the inner parts of the Black Sea Region and provinces such as Konya and Aksaray in the Central Anatolia Region. Crop alternation of sunflower with sugar beet or wheat, especially in the Central Anatolia Region or its replacement in areas where sugar beet cultivation is restricted have contributed significantly to the increase in sunflower production for oil in our country (Onan et al. 1992; Öztürk et al. 2008).

According to 2017 statistics, in our country, 1 million 800 thousand tons of sunflower for oil was produced in 681 thousand hectares of cultivation area and approximately $10 \%$ of the cultivation area and the highest yield taken from the unit area is in Konya (Anonymous 2017). Sunflower consumes less water than sugar beet, corn and carrot plants, which have an important place in Konya's plant pattern. This is one of the reasons for the farmer to prefer sunflower and it is also a suitable plant for alternation with wheat (Yavuz 2016).

Sclerotinia species, one of the crown rot diseases in sunflower cultivation, cause significant losses (Benlioğlu et al. 2004; Kırbağ and Turan 2006; Yıldız et al. 2010; Koike et al. 2013). Sclerotinia diseases are defi- 
ned by different names such as cottony rot, white mold, watery soft rot, stem rot and head rot. The most important pathogen of our study, sunflower crown rot Sclerotinia sclerotiorum (Lib.) de Bary is a disease that is common in almost every region of the world where sunflower is produced, including our country. S. sclerotiorum is distributed in all regions with temperate, tropical or subtropical climates (Gulya et al. 1997). Sclerotinia minor Jagger is also another species that has been reported to cause root rot and wilting on sunflower, but it is much less common than S. sclerotiorum. The pathogen is a polyphagous and facultative parasite and is a host in more than 400 plant species belonging to 75 families (Lazar et al. 2011). Sclerotinia sclerotiorum can remain dormant with its sclerots in dry soil without hosts and causes early infections at the seedling stage (Khan 2007).

For the determination of $S$. sclerotiorum, which causes root and crown rot disease in sunflower in Turkey, Yucer (1980) conducted a study in the Thrace region, Çınar and Biçici (1982) in Çukurova, Cetinkaya and Yildiz (1988) in the Marmara region, Onan et al. (1992) in the Aegean Region, Tozlu and Demirci (2008) in the Pasinler Plain of Erzurum province and reported that it is an important disease of sunflower due to economic losses. Yield loss varies depending on the developmental period of the sunflower. Yield losses can reach $100 \%$ if the infection occurs at the early stage of sunflower development (Lamey et al. 2000; Saharan and Mehta 2008). Sunflower plants infected at the beginning of the flowering stage may lose $98 \%$ of their potential yield, while plants infected 8 weeks after flowering may lose only $12 \%$ of their potential yield (Maširević et al. 2006).

Since cultural measures and the use of resistance varieties are limited in the control against S. sclerotiorum in sunflower and the chemicals used have negative effects and are not economical, early diagnosis of the pathogen is very important in order to develop and increase disease control strategies (Kotan et al. 2009).

In Turkey, there are no studies conducted so far on the presence of fungal diseases that are among the agents that cause yield and quality losses in sunflower production areas in Konya and Aksaray provinces of the Central Anatolia region, which have a significant share in sunflower production. Therefore, this study aims to investigate $S$. sclerotiorum, which causes root and crown rot disease in sunflower production areas of Konya and Aksaray provinces of Central Anatolia Region. Although studies related to sunflower diseases in Turkey are limited in number, at least researching and analyzing the situation in the region will be of great importance in terms of providing important contributions to the literature as well as guiding and informing the producers of the region and the relevant organizations for the struggle.

\section{Materials and Methods}

\subsection{Mateial}

\subsubsection{Test pathogen fungus}

In our study, Sclerotinia sclerotiorum isolates obtained from diseased sunflower plants cultivated in Konya and Aksaray provinces were used as test pathogens. The isolates were grown on Potato Dextrose Agar (PDA) medium with streptomycin sulfate $0.9 \mathrm{~g} / \mathrm{L}$. Potato Dextrose Agar (PDA) is a general purpose nutrient medium used for the cultivation of a large number of fungi and yeasts. It was supplemented with acid or antibiotic (40 mg streptomycin sulfate / $100 \mathrm{ml}$ ) to inhibit bacterial growth. The nutrient medium was prepared as $4.0 \mathrm{~g} / \mathrm{lt}$ Potato Extract, $20.0 \mathrm{~g} / \mathrm{lt}$ Dextrose, $20.0 \mathrm{~g} / \mathrm{lt}$ Agar and adjusted to $\mathrm{pH} 6.8$ (Dhingra and Sinclair 1995).

\subsubsection{Test plant}

In the study, the sunflower plant was used as the host. When selecting the sunflower plant variety, the most cultivated varieties in the villages of Aksaray province, where $S$. sclerotiorum is common, were taken into consideration. Considering this, "İnegöl Alas1", which is a sunflower variety for snack, was selected to be used in our study. The variety that has a wide cultivation area in the Aksaray region was obtained from the producers.

\subsubsection{Cultivation environments used in pot experiments}

In the pathogenicity test, sterile peat and perlite mixture at a ratio of 3: 1 in pots and 15-15-15 (N-P-K) commercial compound fertilizers were used for cultivation environments. The experiments were carried out with 2.5 lt $(130 \times 180 \mathrm{~mm})$ volume plastic pots.

\subsection{Method}

\subsubsection{Disease survey}

Sunflower cultivation areas in districts of Konya (Karatay, Altınekin, Cihanbeyli, Karapınar, Kadınhanı and Çumra) and Aksaray provinces (Center (Hırkatol and Topakkaya villages) and Eskil) were selected as survey areas. In the surveys conducted between June and September of 2017 and 2018, quite a lot of fields were examined and diseased and healthy plants were counted. The samples taken from the fields were examined as 20 plants per $1-5 \mathrm{da}, 40$ plants per 6-10 $\mathrm{da}$, and 60 plants in fields larger than $10 \mathrm{da}$.

In order to determine the disease rates (\%), at least 60 plants were selected from the areas selected from each province, in randomly determined rows, with approximately 10 plants each. Diseased and healthy sunflowers taken from different points of the field were counted, the results were converted into percentages and disease rates were calculated according to Bora and Karaca method (1970).

\subsubsection{Isolation from diseased plants}

Diseased plant samples collected from the study areas constituted the main material of the study. Depending on the number of diseased plants, 5-10 plants 
were sampled per field and used for isolation. After the plant samples brought to the laboratory to isolate the agent were washed in tap water, the pieces or sclerotiums taken were disinfected superficially in $1 \%$ sodium hypochlorite $(\mathrm{NaOCl})$ for 1-2 minutes, then rinsed 3 times in sterile distilled water, and left to dry for $5 \mathrm{mi}-$ nutes on sterile blotting paper in a laminar flow cabinet. Then, each sample was planted in 2 petri dishes on Potato Dextrose Agar (PDA + Streptomycin sulphate) medium. 3-4 diseased tissue pieces were planted in each petri dish. These petri dishes were left to incubation at $20-25^{\circ} \mathrm{C}$ and started to be monitored from the 2nd day. Pure cultures were obtained by transferring micellar discs of $5 \mathrm{~mm}$ diameter taken from the tip of colonies that developed from tissue pieces or sclerotiums within 2-3 days to petri dishes containing PDA. These $S$. sclerotiorum isolates were kept in a refrigerator at $10^{\circ} \mathrm{C}$ and used in the next sta-ges of the study.

\subsubsection{Identification of the isolates}

It has been stated that it is possible to separate sclerotiums by size in order to define $S$. sclerotiorum and determine its differences from other species (Ekins et al 2005). The width and length of 5 sclerotium obtained from each isolate developed in PDA for 3 weeks were measured with a caliper and the arithmetic averages of the obtained values were taken (Lucas 1998).

\subsubsection{Pathogenicity test}

Pathogenicity was established with 4 repetitions according to the Random Parcel Trial Pattern and 2 (two) S. sclerotinia isolates obtained from sunflower fields in Aksaray province were applied to sunflower seedlings as a limited time stem inoculation method.
When the plants are in the R2 stage, which is the beginning of flowering (Nelson et al 1988), the mycelium discs of $4 \mathrm{~mm}$ diameter taken from the actively growing parts of the cultures of S. sclerotiorum developed in PDA for 7 days, were inoculated by placing a mycelium disc on each plant and into the wounds opened to the stem of the plant with a diameter of $5 \mathrm{~mm}, 4$ $\mathrm{cm}$ above the soil surface, and wrapped with parafilm. The sterile PDA discs were placed in control plants. At the end of the incubation period (7 days), the length of light or dark brown lesions on the stem was measured from the point of inoculation with a digital caliper. 1-6 Root rot scale modified according to James (1971) (1: No symptoms in the plant, 2: Area with 1-10\% necrosis, 3: Area with 10-25\% necrosis, 4: Area with 2550\% necrosis. 5: Area with 50-75\% necrosis, 6: Area with $75-100 \%$ necrosis) was used and the disease severity (\%) was calculated according to the Townsend-Heuberger (1943) formula.

The obtained data were analyzed with one-way ANOVA using the SPSS statistical program (SPSS Inc., version 17.0) and the significant differences between the averages were determined by Tukey multiple com-parison test $(\mathrm{P} \leq 0.05)$.

\section{Results and Discussion}

\subsection{The results of disease survey}

Sunflower production areas in Konya and Aksaray districts were continuously checked with an average interval of 20-30 days (30, 45, 60 and 90 days) starting from June (emergence) in 2017 and 2018. The results of the years surveyed in Konya are given in Table 1.

Table 1

Ratio (\%) of White Rot Disease (Sclerotinia sclerotiorum) in Sunflower cultivation areas of Konya province

\begin{tabular}{|c|c|c|c|c|c|c|c|}
\hline Years & Location & $\begin{array}{c}\text { Production } \\
\text { Area (da) }\end{array}$ & $\begin{array}{l}\text { Number of } \\
\text { fields sur- } \\
\text { veyed }\end{array}$ & $\begin{array}{c}\text { Survey } \\
\text { area (da) }\end{array}$ & $\begin{array}{c}\text { Number of } \\
\text { diseased fields }\end{array}$ & $\begin{array}{c}\text { Infestation } \% \\
\text { of field }\end{array}$ & $\begin{array}{l}\text { Disease } \\
\text { rate }(\%)\end{array}$ \\
\hline \multirow{6}{*}{2017} & Karatay & 183710 & 25 & 1900 & 0 & 0 & 0 \\
\hline & Karapınar & 96000 & 20 & 1000 & 0 & 0 & 0 \\
\hline & Cihanbeyli & 83765 & 12 & 900 & 0 & 0 & 0 \\
\hline & Altınekin & 79904 & 24 & 850 & 0 & 0 & 0 \\
\hline & Kadınhanı & 78500 & 13 & 800 & 0 & 0 & 0 \\
\hline & Çumra & 36670 & 14 & 400 & 0 & 0 & 0 \\
\hline \multirow{5}{*}{2018} & Karatay & 204743 & 32 & 2100 & 0 & 0 & 0 \\
\hline & Karapınar & 71523 & 13 & 700 & 0 & 0 & 0 \\
\hline & Altınekin & 109002 & 28 & 1300 & 8 & 28 & 9,38 \\
\hline & Kadınhanı & 76255 & 15 & 800 & 0 & 0 & 0 \\
\hline & Çumra & 88722 & 16 & 900 & 0 & 0 & 0 \\
\hline
\end{tabular}

While no plants showing symptoms such as root and crown rot, wilting, growth retardation, weak plant growth were occurred in 5,850 da area surveyed in 2017, abiotic related problems were observed more (Table 1). In 2018, S. sclerotiorum was detected in $4.74 \%$ of 5,900 da area, and abiotic related problems seen in the previous year were occurred again. Monthly (6th and 7th months) average relative humidity is $40.4 \%$ in Konya province while the average temperature is $24^{\circ} \mathrm{C}$, and these climatic values are thought to prevent the emergence of the disease (S. sclerotiorum). Because the importance of humidity and precipitation in the development of the disease has been emphasized in many studies (Çetinkaya and Yıldız 1998; Huang et 
al. 1998; Matheron and Porchas 2000). Considering the average humidity, temperature and monthly precipitation data in Konya / Altınekin district, it is predicted that there are increasing values between 2017-2018 and that disease agents causing sunflower root rot may appear in this region in 2018. Considering these evaluations, a disease agent was encountered in the Oguzeli village of Altınekin during the 2018 surveys. As a result of the examination, 45 of 480 plants examined were found to be diseased and the disease rate was determined as $9.38 \%$. In addition to climate data, faulty

Table 2

Ratio (\%) of White Rot Disease (Sclerotinia sclerotiorum) in Sunflower cultivation areas of Aksaray province

\begin{tabular}{cccccccc}
\hline Years & Location & $\begin{array}{c}\text { Production } \\
\text { Area (da) }\end{array}$ & $\begin{array}{c}\text { Number of } \\
\text { fields surve- } \\
\text { yed }\end{array}$ & $\begin{array}{c}\text { Survey } \\
\text { area (da) }\end{array}$ & $\begin{array}{c}\text { Number of } \\
\text { diseased fields }\end{array}$ & $\begin{array}{c}\text { Infestation } \% \\
\text { of field }\end{array}$ & $\begin{array}{c}\text { Disease } \\
\text { rate }(\%)\end{array}$ \\
\hline \multirow{2}{*}{2017} & Merkez & 49950 & 13 & 600 & 3 & 23 & 2,83 \\
& Eskil & 86500 & 20 & 900 & 0 & 0 & 0 \\
2018 & Merkez & 64825 & 17 & 800 & 5 & 29 & 3,97 \\
& Eskil & 65066 & 18 & 700 & 4 & 4,16 \\
\hline
\end{tabular}

The disease rate in the center was $2.83 \%$ in 2017 , it was $3.97 \%$ in 2018 . While no disease was occurred in Eskil in 2017, the disease rate was $4.16 \%$ in 2018 (Table 2). $23 \%$ of the survey area in the Aksaray region was infected with S. sclerotiorum in 2017. In 2018 surveys, it was observed that the disease occurred in districts where there was no disease in the previous year, and the rate of infection was between $22 \%$ and $29 \%$. There may be different reasons for the emergence of the disease to increase compared to previous years or for the emergence of the disease in districts where it has never appeared. The disease started to appear in increasing density due to the fact that sunflower producers do not fully comply with the alternation in the production areas, successive sunflower cultivation is widespread, the time of cultivation is not appropriate, the cultivation is performed frequently, the diseased plant residues are not destroyed and the surface irrigation (wild irrigation) is applied. Crop rotation should be initiated before the pathogen becomes a serious problem in an area, and cultivating non-host crops for 3-5 years will reduce the number of sclerotia in the soil and minimize the impact of sunflower root infection (Gulya et al. 1997; Rashid 2003).

The fact that monthly (6th and 7th months) average relative humidity of Aksaray is quite high at $60 \%$ and the average temperature is around $21,6^{\circ} \mathrm{C}$ and lower than other provinces can be considered among the reasons why the disease is seen in this region. Sclerots from the previous year are the most important means of $24 \%$ soil moisture. However, destructive infections occur when sensitive plants are close (Irany et al. 2001; Lazar et al. 2011). penetration and their germination is best performed at agricultural processes have triggered the emergence of disease. In particular, entering alternation for only 1 year, not leaving the field fallow and excessive irrigation are examples of these and also show that this disease may increase in the coming years. Among them, long-term crop rotation is very important in combating the pathogen ( $S$. sclerotiorum) before it becomes a serious problem in a region (Rashid 2003).

The results of the surveys carried out in the sunflower fields of Aksaray province in 2017-2018 are given in Table 2.

\subsection{Isolation results and symptoms of the disease}

When the sunflower fields were visited during the vegetation period, it was found that Sclerotinia sclerotiorum was the white rot agent of the disease which was obtained as a result of both macroscopic observations and isolations performed from diseased plants.

In the observations about the pathogen, it was seen that irregularly shaped light and dark brown lesions starting from the base of the sunflower stem and the expansion of these lesions in time led to the symptoms of cottony mycelium. The disease spreads completely by covering the stem. The most obvious and typical symptom of the pathogen is the formation of amorphous sclerotium on the infected sunflower stem, which are initially white but then turn black on the outside and begin to harden. Over time, the stem of the infected plant can be broken easily by taking a thready appearance, and sclerotiums are seen to form when these parts are opened. Similar symptoms were observed in a survey carried out on sunflower in Pasinler plain of Erzurum and $169 \mathrm{~S}$. sclerotiorum isolates were obtained in isolation from roots (Tozlu 2003).

S. sclerotiorum was found in only 1 locality in Konya and 3 different localities in Aksaray. As a result of a 2-year survey study, 2 isolates from Aksaray Province Center (Topakkaya village) in 2017, 4 isolates from Aksaray Province Center (Hirkatol village), 3 isolates from Eskil (Kökez village), 1 isolate from Konya province Altınekin (Oguzeli village) was obtained. Thus, a total of 10 isolates were determined.

\subsection{Identification of isolates}

The agents of white rot disease are S. sclerotiorum and $S$. minor, and the distinction of these two species is based on the size of the sclerotium. S. minor forms more, small, irregular sclerots. It was determined that 
all isolates belong to $S$. sclerotiorum by the measurements of sclerot sizes of the isolates obtained as a result of the isolations. When all localities are considered in general, the length of the sclerots varies between 4.4-8.19 $\mathrm{mm}(5.8 \mathrm{~mm})$ and the width is between 2.13 and $5.9 \mathrm{~mm}(4.0 \mathrm{~mm})$. The results in this study are in accordance with the sclerots of $S$. sclerotiorum in the literature with sizes ranging from 5-20 mm (Singleton 1992) and 3-10 mm (Ekins et al. 2005).

\subsection{Pathogenicity test of isolates}

In pathogenicity tests, Aksaray (Eskil and Hirkatol) isolates obtained from the regions where the disease occurred for two consecutive years were used and it was found that the scale values of the isolates varied

Table 3

Disease severity rate (\%) of Sclerotinia sclerotiorum isolates

\begin{tabular}{lcc}
\hline Isolates & Average lesion lengths $(\mathrm{cm})$ & Disease severity $(\%)$ \\
\hline Aksaray/Hırkatol & $11 \mathrm{a}$ & $66 \mathrm{a}$ \\
Aksaray/Eskil (Kökez) & $7.5 \mathrm{~b}$ & $56 \mathrm{~b}$ \\
\hline
\end{tabular}

between 5-6. As a result of the pathogenicity tests, a difference was observed between the lesion lengths of the symptoms (Table 3). When the lesion lengths of the repetitions were evaluated in general, Hirkatol isolate was measured as the highest $12 \mathrm{~cm}$ and the lowest 10 $\mathrm{cm}$, and the Eskil (Kökez) isolate as the highest $9.5 \mathrm{~cm}$ and the lowest $5.5 \mathrm{~cm}$. It was observed that this difference is related to the humidity and precipitation during the vegetation period, which was supported by the studies (Minkevich and Kosorukova 1987; Tozlu 2003; Onaran 2009). Both isolates were observed to cause complete death in plants and are highly virulent. Differences in virulence among the isolates of S. sclerotiorum have been revealed by many researchers (Marciano et al. 1983; Kohn et al. 1990).

* There is no statistical difference between groups bearing the same letters $(\mathrm{P}<0.05)$

One of the most important reasons why the disease severity occurs most in the isolate taken from Hirkatol is thought to be caused by the continuous cultivation of the same product due to the intensive sunflower cultivation in this region. In many studies, the reason for the high inoculum density has been reported to be due to the continuous cultivation of the same crop in the same fields and continuous precipitation (Morton and Hall 1989; Dorrance and Lipps 2002).

\section{Conclusion}

In the study, it was determined that the agent that causes white rot disease in sunflower cultivation areas in Konya and Aksaray provinces is a fungal agent named S. sclerotiorum. Determining the disease in sunflower is important since no detailed studies have been carried out in these regions before.

In the study, it was aimed to determine the prevalence rates of $S$. sclerotiorum and it was observed that the disease appeared at increasing rates in the districts of Aksaray every year and the average disease rate for two years was found to be $3.5 \%$. As a matter of fact, in studies conducted on sunflower in our country, it has been stated that the prevalence of $S$. sclerotiorum varies between 2.5-100\% (Onan et al. 1992; Demirci and Kordalı 1998; Tozlu 2003).

In Konya province, the course of the disease, which was observed only in the second year, was quite high with a rate of $9.38 \%$. Altınekin District Directorate of Agriculture and the producers stated that the disease was seen several times in previous years. Considering the temperature and humidity values of 2017 , it is thought that the emergence of the disease may increase in the following years. In addition, it can be said that the amount of inoculum will increase over the years de- pending on sunflower production and even this disease will cause an epidemic by posing a potential danger. It is thought that detecting the areas where S. sclerotiorum may occur and diagnosing the disease will contribute greatly to combat this pathogen and reduce its inoculum potential.

\section{Acknowledgements}

This study has been produced from a part of the first author's doctorate thesis prepared under the supervision of the second author. This research was supported by a grant from the Coordinatorship of the Scientific Research Projects of Selçuk University (Project Number: 18101017).

\section{References}

Anonymous (2016). 2016 Sunflower Report. Republic of Turkey, Ministry of Customs and Trade, General Directorate of Cooperatives (Access date: 04.02.2017).

Anonymous (2017). Turkish Statistical Institute (TUIK) crop production statistics.

Benlioğlu S, Yıldız A, Döken T (2004). Studies to determine the causal agents of soil-borne fungal diseases of strawberries in Aydin and control them by soil disinfestation. Journal Phytopathology 152: 509-513.

Bora T, Karaca I (1970). Kültür bitkilerinde hastalığın ve zararın ölçülmesi. Ege Üniversitesi. Bornova, $\mathrm{P}: 39$.

Çetinkaya N, Yıldız M (1988). Bazı ayçiçeği çeşit ve hatlarının Sclerotinia türlerine reaksiyonları üzerinde çalışmalar. IX. Ulusal Biyoloji Kongresi, Sivas, 151-158. 
Çınar A, Biçici M (1982). Çukurova'da ayçiçeği parsellerinde görülen tabla çürüklüğü ile kök boğazı ve gövde yanıklıgı hastalıklarının etiyolojisi ve önemi. III. Türkiye Fitopatoloji Kongresi Bildirileri (12-15 Ekim, 1982), Adana, 68-79.

Demirci E, Kordalı Ş (1998). Pasinler ovasında ayçiçeğinde rastlanan funguslar. Türkiye VIII. Fitopatoloji Kongresi Bildirileri, Ankara, 314-317.

Dhingra OD, Sinclair JB (1995). Basic plant pathology methods. Second Edition, Lewis Publishers, CRC Press, USA, 400-450.

Dorrance AE, Lipps PE (2002). Sclerotinia white mold of soybean, (online) Available at http://ohioline.osu.edu/act-fact/0045.html.

Ekins MG, Aitken EAB, Goulter KC (2005). Identification of Sclerotinia species. Australasian Plant Pathology 34: 549-555.

Gulya TJ, Rashid KY, Masirevic SM (1997). Sunflower diseases. In: Schneiter, A. A. (Ed.). Sunflower technology and production. Madison: American Society of Agronomy p. 263-379.

Huang HC, Chang C, Kozub GC (1998). Effect of Temperature During Sclerotial Formation, Sclerotial Dryness, and Relative Humidity on Myceliogenic Germination of Sclerotia of Sclerotinia sclerotiorum. Canadian Journal of Botany 76(3): 494-499.

Irany H, Ershad D, Alizadeh A (2001). The effect of soil depth, moisture and temperature on sclerotium germination of Sclerotinia sclerotiorum and its pathogenicity. Iranian Journal of Plant Pathology 37: $185-195$.

James C (1971). A manual of Assessment Keys for Plant Diseases. Canada Dep. Agric. Pupl. 1458.

Khan SN (2007). Macrophomina phaseolina as causal agent for charcoal rot of sunflower. Mycopathologia 5: 111-118.

Kırbağ S, Turan N (2006). Malatya'da yetiştirilen bazı sebzelerde kök ve kökboğazı çürüklüğüne neden olan fungal etmenler. Firat Üniv. Fen ve Müh. Bil. Dergisi 8 (2): 159-164.

Kohn LM, Carbone I, Anderson JB (1990). Mycelial interactions in Sclerotinia sclerotiorum. Exp Mycol 14:255-267.

Koike ST, Gordon TR, Daugovish O, Ajwa H, Bolda M, Subbarao K (2013). Recent Developments on Strawberry Plant Collapse Problem in California Caused by Fusarium and Macrophomina. Proceedings of the 2011 North American Strawberry Symposium. Page 76-83. International Journal of Fruit Science 13 (1-2): 76-83,2013.

Kotan R, Dikbaş N, Bostan H (2009). Biological control of post harvest disease caused by Aspergillus flavus on stored lemon fruits. African Journal of Biotechnology 8 (2): 209-214.

Lamey A, Knodel J, Endres G, Gregoire T, Ashley R (2000). Sunflower disease and midge survey. NDSU, Extension Service, Fargo, ND. http://www.ag.ndsu.nodak.edu. Accessed on September 10, 2014.

Lazar A, Lupu EA, Leonte C (2011). Researches on resistance some sunflower hybrids to the artificial infection with Sclerotinia sclerotiorum. Seria Agron 54:

Lucas JA (1998). Plant Pathology and Plant Pathogens (3rd ed.). Blackwell Science, Oxford, pp. 274.

Marciano P, Dileena P, Magro P (1983). Oxalic acid, cell wall degrading enzymes and $\mathrm{pH}$ in pathogenesis and their significance in the virulence of two Sclerotinia sclerotiorum isolates on sunflower. Physiological Plant Pathology 22: 339-345.

Maširević S, Jasnic S (2006). Root, stem and head rot of sunflower. Biljni Lekar (Plant Doctor) 34: 336343.

Matheron ME, Porchas M (2000). Comparison of New Fungucides to Mana- ge Sclerotinia Leaf Drop of Lettuce in 2000. (online) Available at http://ag.arizona.edu/pubs/crops/az.177.

Minkevich II., Kosorukova LA (1987). Climate and weather effects on sunflower mycoses along the lower Volga and their forecasting. Mikologiya I Fitopatologiya, 21: 365-369.

Morton JG, Hall R (1989). Factors determining the efficacy of chemical control of white mold in white bean. Canadian Journal of Plant Pathology 11:297302.

Nelson B, Duval D, Wu H (1988). An in vitro tecnique for large-scale production of sclerotia of Sclerotinia sclerotiorum. Phytopathology 78: 1470-1472.

Onan E, Çimen M, Karcılığlu A (1992). Fungal diseases of sunflovver in Aegean Region of Türkiye. Journal of Turkish Phytopathology 21: 101-107.

Onaran A, Yanar Y (2009). Türkiye'de Sclerotinia sclerotiorum (Lib.) De Bary üzerinde yapılan çalışmalar. Türk Bilimsel Derlemeler Dergisi 2(2): $75-80$.

Öztürk Ö, Akınerdem F, Bayraktar N, Ada R (2008). Konya sulu koşullarında bazı hibrit ayçiçeği çeşitlerinin verim ve önemli tarımsal özelliklerinin belirlenmesi. S. U. Ziraat Fakültesi Dergisi, 22 (45): 1120.

Rashid KY (2003). Diseases of sunflower. In: Diseases of Field Crops in Canada, eds., K.L. Bailey, B.D. Gossen, R.K. Gugel, and R.A.A. Morrall. The Canadian Pyhtopathology Society, Ottawa, Ontario, Canada, pp. 169-176.

Saharan GS, Mehta N (2008). Sclerotinia Diseases of Crop Plants: Biology, Ecology and Disease Management, Vol. LXII. Springer-Verlag GmbH, Heidelberg, Germany.

Singleton LL, Mihail JD, Rush CM (1992). Methods For Research on Soilborne Sons Inc. USA.433p.

Tekçe A (2015). Türkiye'de Ayçiçek tohumu ve Ayçiçek yağı üretimi, arz talep dengesi. Yă̆lı Tohumlu 
Bitkiler ve Bitkisel Yağlar Konferansı, 3 Eylül 2015, İstanbul s. 57.

Townsend GK, Heuberger JW (1943). Methods for Estimating Losses Caused by Diseases in Fungicide Experiments. Plant Dis. Reptr. 27; 340-343.

Tozlu E (2003). Pasinler Ovası'nda Ayçiçeğinde Gövde Çürüklüğü Hastalığını Oluşturan Sclerotinia sclerotiorum (Lib.) de Bary ve Sclerotinia minor Jagger'ın Yayılışı, Tanılanması, Patojeniteleri Ve Biyolojik Kontrolü. Atatürk Üniversitesi Fen Bilimleri Enstitüsü Basılmamış Doktora Tezi, 117, Erzurum.

Tozlu E, Demirci E (2008). Erzurum-Pasinler Ovası'nda ayçiçeğinde Sclerotinia sclerotiorum ve $S$. minor tarafindan oluşturulan gövde çürüklüğü hastalığının yaygınlığı, etmenlerin tanılanması ve bazı ayçiçeği çeşitlerinin hastalık etmenlerine reaksiyonu. Bitki Koruma Bülteni 48(4): 19-33.

Yavuz N (2016). Farklı Sulama Aralığı ve Kısıtlı Sulamanın, Ayçiçeği Verim ve Kalitesi Üzerine Etkisi. Selçuk Üniversitesi, Fen Bilimleri Enstitüsü, Tarimsal Yapılar ve Sulama Anabilim Dalı. Doktora Tezi.

Yıldız A, Benlioğlu S, Benlioğlu K, Boz Ö (2010). Use of different plastics for soil solarization in strawberry growth and time- temperature relationships for the control of Macrophomina phaseolina and weeds. Phytoparasitica 38: 463-47.

Yücer MM (1980). Trakya bölgesinde ayciceklerinde görülen hastalıkların oranı, fungal etmenleri ve etmenlerin patojenitesi üzerinde araştırmalar. İstanbul Böl. Zir. Müc. Araş. Enst. Md. Eserleri Serisi, 14, Ankara, $96 \mathrm{~s}$. 